\title{
Stabilization of encapsulated probiotics from the bacterium Lactobacillus casei by different drying techniques
}

\author{
Acosta-Piantini, E. M. ${ }^{\text {**; }}$ Villarán, M. C. ${ }^{\text {b }}$ Lombraña, J. I. ${ }^{\mathbf{c}}$ \\ a, c Dept. of Chemical Engineering. F. of Science and Technology UPV/EHU. P.O. Box 644. 48080 \\ Bilbao (Spain) \\ b Tecnalia foundation, Alava Technology Park, Spain \\ *E-mail of the corresponding author: eacosta004@ikasle.ehu.eus
}

\begin{abstract}
The main objective of this work is to encapsulate and dry the bacterium probiotic Lactobacillus casei applying three different drying techniques (lyophilization, fluidized bed and flash freeze drying) as well as to evaluate their viability during storage in the dark at $20^{\circ} \mathrm{C}$ and $34 \%$ relative humidity for 28 days. In addition, to compare viability of the bacterium processed with flash freeze drying with cryoprotectant (skim milk) and without cryoprotectant.

In the case of flash freeze drying, the final level of viability shows the potential of this drying technique with much less operating costs than lyophilization.
\end{abstract}

Keywords: Encapsulated, probiotics, lactobacillus, casei, drying 


\section{Introduction}

Encapsulation and drying techniques are alternatives which trying to protect probiotics microorganisms of the effect of environmental agents that may affect their viability, during processing, storage and consumption and their passage through the gastrointestinal tract by allowing them to maintain their viability and functionality over time [1, 2] by reducing cell damage to retain cells within encapsulation materials that generate their isolation [3, 4].

Probiotic bacteria are live microorganisms which when administered in adequate amounts confer health benefits to the host, beyond their inherent nutritional contribution $[5,6]$. The bacteria are encapsulated, dried and converted into powder for use in food and pharmaceutical applications, as the powder is easy to handle, transport and store. Different drying techniques can be used for the encapsulation of probiotics.

In this project we evaluated flash freeze drying, lyophilization and fluidized bed.

Flash freeze drying (FFD process is developed by the freezing of the product through the application of vacuum. Then, a considerable fraction of water is removed by vaporization during freezing and once frozen the rest by sublimation, obtaining in this way a dry paste which favours the preservation of the product [7]. This technology enables the encapsulation of biological materials to reduce the rate of chemical reactions and degradation by heat [8].

Many factors responsible for microbial survival have been reported during and after the freeze-dried, among them, the bacterial species, the physiological state, cell density, effect of protectors [9], freezing rates and other process parameters, as well as rehydration [10].

Lyophilisation is a technique which also is developed by the freezing of the product and after the application of vacuum, the water is removed only by sublimation while Fluidized Bed Drying is a process in which heated gas is, usually conditioned air with controlled velocity, is passed through a bed of suspending solid particles, dragging the removed water.

The main objective of this work is to encapsulate and dry the bacterium probiotic Lactobacillus casei applying different drying techniques as well as to evaluate their viability during storage. In addition, to compare the viability of the bacterium L casei, processed with Flash Freeze Drying with cryoprotectant (skim milk) and without cryoprotectant.

\section{Materials and Methods}

Lactobacillus casei 431 biomass was produced using Man Rogosa Sharpe (MRS) culture medium. The final probiotic required an encapsulation treatment with alginate and chitosan in a Jet-cutter equipment, and then dried by three different treatments: Flash freeze drying (FFD), lyophilization and fluidized bed. 
Probiotics were packaged in vacuum, stored in the dark at $20^{\circ} \mathrm{C}$ and $34 \%$ relative humidity for 28 days. Measurements of water activity and microbiological analysis were performed on the $7^{\text {th }}, 14^{\text {th }}, 21^{\text {st }}$ and $28^{\text {th }}$ days of storage.

\subsection{Obtaining of microbial biomass}

Strains of L. casei 431 were supplied by Christian Hansen \& Cia and kept in their original packaging at temperature of $-80^{\circ} \mathrm{C}$. They were activated in MRS broth and incubated at 37 ${ }^{\circ} \mathrm{C}$ for 24 hours under aerobic conditions with moderate stirring (200 rpm). Biomass recovered by centrifugation $\left(4000 \mathrm{rpm}\right.$ at $\left.15^{\circ} \mathrm{C}\right)$. The centrifuged fraction presented a concentration of cells around of $10^{9}$ units forming colonies (CFU) per gram and the supernatant was discarded. Finally, the cells were washed with sterile water, and preserved in refrigeration $\left(6 \pm 2^{\circ} \mathrm{C}\right)$ until used.

\subsection{Encapsulation}

For encapsulation process, we suspended the bacteria in alginate and received it in a bath of Chitosan using a Jett Cutter at following operations conditions: flow 25 g/s, 170 nozzle, pressure 1.5 bar and motor 4,000 rpm. Then, the mass of microcapsules were divided in three groups: a) fluidized bed drying b) lyophilization and c) flash freeze drying. In addition, we divided flash freeze drying in two groups: c.1) with cryoprotectant (skim milk sterile) and c.2) without cryoprotectant.

\subsection{Drying techniques}

Fluidized bed drying (FBD) was made in a Glatt GmbH dryer, model Uni-Glatt, with the following conditions: temperature in air $30^{\circ} \mathrm{C}$, temperature out air $24^{\circ} \mathrm{C}$ and temperature product $12^{\circ} \mathrm{C}$. The process drying was carried out until to obtain the required water activity in the product.

Lyophilization was carried out in a Telstar Lyo beta 25 equipment, with fluid temperature of $5.1^{\circ} \mathrm{C}$, condenser temperature $-76.3^{\circ} \mathrm{C}$ and heating temperature of $23.1^{\circ} \mathrm{C}$, with full cycle of 48 hours, beginning at a freezing temperature of $-40^{\circ} \mathrm{C}$ to 0.1 mbar during 4 hours, followed by a 24 hour primary dried at $40^{\circ} \mathrm{C}$ and 4 hours of secondary drying at $20^{\circ} \mathrm{C}$ and at 0.05 mbar, 10 hours more.

For Flash Freeze Drying (FFD), we used a Telstar Lyo Quest equipment in which pressure was reduced from atmospheric to $0.02 \mathrm{mbar}$ in $30 \mathrm{~min}$ with the heating device at $30{ }^{\circ} \mathrm{C}$ during sublimation.

Dried material was packed in polyethylene bags and stored in controlled temperature $(20 \pm 2$

$\left.{ }^{\circ} \mathrm{C}\right)$ store and moisture relativity of $60 \%$. 


\subsection{Study of bacteria survived and stability}

To determine the effect of the agent cryoprotectant (sterile skim milk) on viability of encapsulated microorganisms, the number of viable cells was determined before and after freeze-drying and drying, every 7 days during storage at $20 \pm 2{ }^{\circ} \mathrm{C}$ for 28 days. We used as criteria of stability: the viability during storage (CFU/g) and water activity. These parameters were determined every seven days by triplicate.

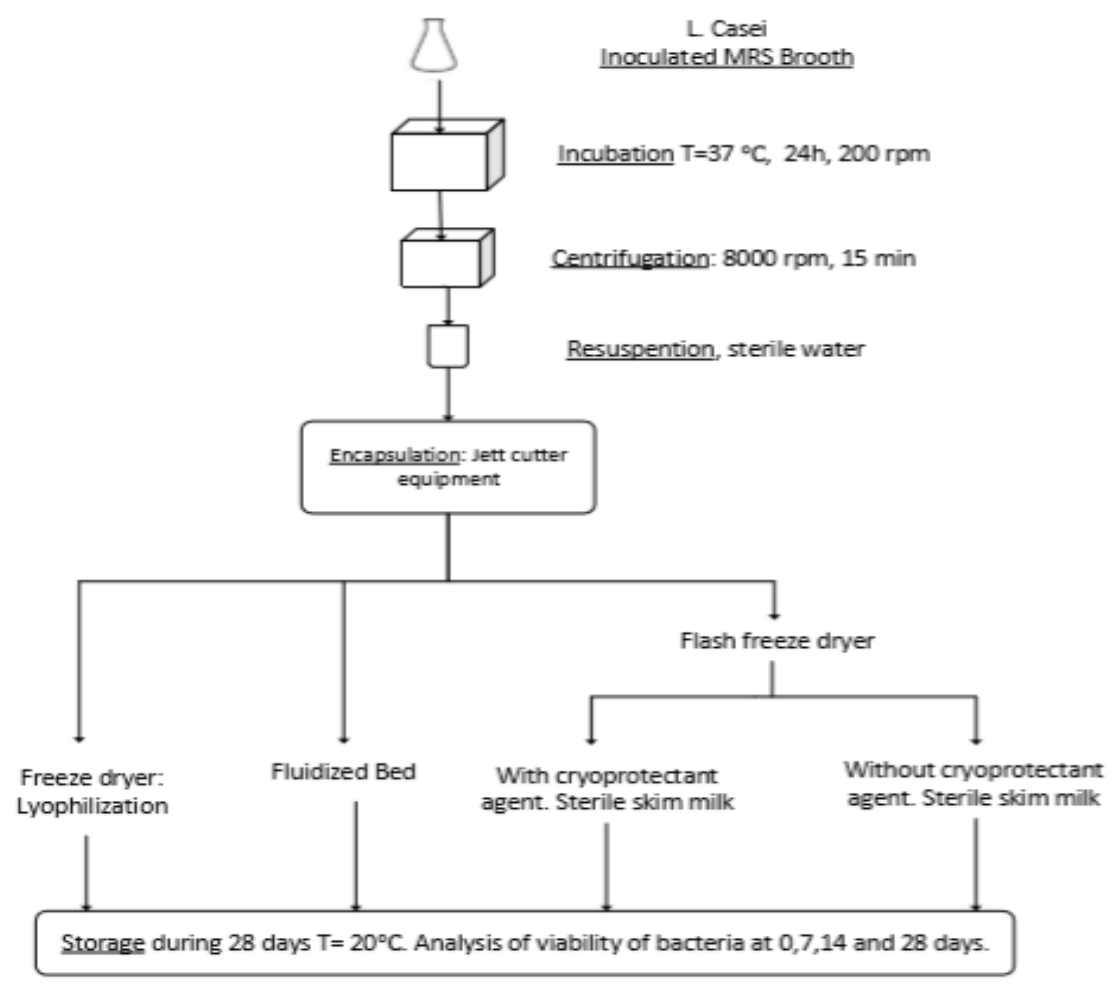

Figure 1. Flowchart with the methodology used for encapsulation and drying L. casei

\subsection{Viability}

Analysis of viability was made taken a gram of encapsulated material, soaked in $10 \mathrm{ml}$ of buffered 0.1 sterile water, homogenized with vortex. A volume of $100 \mu \mathrm{L}$ of dilution it was sown surface on MRS medium and incubated under aerobic conditions at $37^{\circ} \mathrm{C}$ for 48 hours. Counts were performed in duplicate and expressed as cfu g-1 (dry basis), for each experimental condition [11]. The figure 1 show flowchart with the methodology used for encapsulation and drying of $L$. casei. 


\subsection{Physicochemical characterization}

Water activity $\left(\mathrm{a}_{\mathrm{w}}\right)$ was determined in a hygrometer Novasina, Bab master aw, Switzerland.

\subsection{Experimental design and statistical analysis}

An experimental design was applied with a factor (storage time) with repeated measurements where the experimental units were followed over time. The results correspond to the average of three replicates and are presented as mean \pm standard deviation. An analysis of variance (ANOVA) and Tukey test with a level of significance to $\mathrm{p}<0.05$ was applied to the data analysis.

\section{Results and discussion}

\subsection{Drying techniques effect}

The results show significant differences between the results of feasibility among the three treatments, presenting the Fluidized Bed Drying (FBD) the lower viability. Besides, there were significant differences between the water activity of capsules treated in three treatments, showing freeze-dried capsules the lower water activity.

After FFD, see Table 1, the bacterium presented a viability level of $5.3 \times 10^{10} \mathrm{CFU} / \mathrm{g}$, which is equivalent to $84.49 \%$ survival, only a little less than by lyophilization, in which the viability test gave $7.9 \times 10^{10} \mathrm{CFU} / \mathrm{g}$ or an $86.19 \%$ survival.

In the case of FFD, although a certain decrease in viability during storage was observed, from $5.1 \times 10^{10} \mathrm{CFU} / \mathrm{g}$ ( $7^{\text {th }}$ day) to $4.7 \times 10^{9} \mathrm{CFU} / \mathrm{g}$ (28 $8^{\text {th }}$ day), or a survival variation from 99.8 to $90.3 \%$, the final level of viability is important because shows the potential of this technical drying.

Table 1. Cell survival after drying and during storage for the three drying techniques. The values of $a_{w}\left(20^{\circ} \mathrm{C}\right)$ correspond to the end of drying

\begin{tabular}{|c|c|c|c|c|c|}
\hline \multirow{2}{*}{$\begin{array}{l}\text { Drying } \\
\text { technique }\end{array}$} & \multicolumn{2}{|c|}{ Cell viability* - Drying } & \multirow{2}{*}{$\begin{array}{l}\text { Water } \\
\text { activity } \\
\left(\mathbf{a}_{\mathrm{w}}\right)\end{array}$} & \multicolumn{2}{|c|}{ Cell viability** - Storage } \\
\hline & Before & After & & $7^{\text {th }}$ day & $28^{\text {th }}$ day \\
\hline Lyophilization & 4.4 E12 & 7.9E10 (86.19) & 0.0993 & 7.2E10(99.6) & 6.2 E9 (90.19) \\
\hline FBD & $5.1 \mathrm{E} 12$ & 7.1E8 & 0.3075 & $8.1 \mathrm{E} 7$ & 0 \\
\hline FFD & $4.92 \mathrm{E} 12$ & 5.3E10 (84.49) & 0.0775 & 5.1E10(99.8) & 4.7 E9 (90.3) \\
\hline
\end{tabular}

* Cell viability values are expressed in CFU/g, numbers between brackets are the survival percent respect to the cell content before drying.

** In the case of storage, numbers between brackets are the survival percent respect to the cell content after drying. 


\subsection{Storage}

Respect to the dried stored samples the results show that the L. Casei lyophilized presented at the end of the 28th day of storage a viability level of $5.3 \times 10^{10} \mathrm{CFU} / \mathrm{g}$, which is equivalent to $84.49 \%$ survival, only a little less than by lyophilization, in which the viability test gave $7.9 \times 10^{10} \mathrm{CFU} / \mathrm{g}$ or an $86.19 \%$ survival.

In the case of FFD, see Table 1, although a certain decrease in viability during storage was observed, from $5.1 \times 10^{10} \mathrm{CFU} / \mathrm{g}$ ( $7^{\text {th }}$ day) to $4.7 \times 10^{9} \mathrm{CFU} / \mathrm{g}\left(28^{\text {th }}\right.$ day), or a survival variation from 99.8 to $90.3 \%$, the final level of viability is important because shows the potential of this drying technique with much less operating costs than lyophilization. [12]

\subsection{Physicochemical properties}

Water activity values are considered critical parameters for the survival of micro-organisms and on the stability of microcapsules during storage. Measurements were made at the beginning and end of storage, and they are reported in the Table 1.

Some authors claim that the adverse effect or not, of the drying techniques is related to aspects as the bacterial species, the addition of protective substances, initial cell concentration, physiological state of microorganisms, rate of freezing by the generation of osmotic stress, temperature and conditions of rehydration, among others [13]. In this study FBD presents the lowest water activity, which encourages the preservation of probiotic material.

\section{Conclusions}

Flash Freeze Drying (FFD) is set to become a promising drying technique with similar results to lyophilization but with much less process time and operating costs.

The use of milk as a protectant showed advantages on the results of feasibility, so its use is recommended.

The importance of these results reveal that, under adequate drying treatment, it is possible to stabilize probiotic material with Flash Freeze Drying (FFD) process in viable conditions for extending its shelf life. 


\section{Nomenclature}

$\begin{array}{ll}\mathrm{g} / \mathrm{s} & \text { grams per second } \\ \text { mbar } & \text { milibar } \\ \mathrm{ml} & \text { millilitre } \\ \mu \mathrm{L} & \text { microlitre } \\ { }^{\circ} \mathrm{C} & \text { Celsius degrees } \\ \mathrm{rpm} & \text { revolutions per minute } \\ \mathrm{CFU}^{\mathrm{g} g} & \text { colony forming units per gram } \\ \mathrm{a}_{\mathrm{w}} & \text { Water activity }\end{array}$

\section{Acknowledgements}

The authors thank for technical and human support provided by SGIker of UPV/EHU and European funding (ERDF and ESF), and the Ministery of Higher Education, Science and Technology and FONDOCYT of the Dominican Republic.

\section{References}

[1] Semyonov, D.; Ramon, O.; Levin-Brener, L.; Gurevich N. S. E. Microencapsulation of Lactobacillus paracasei by spray freeze drying. Food Res Int, 2010, 43, 193-202.

[2] González, R. E. J.; Mendoza, L.; Morón, B. Efecto de la Microencapsulación sobre la Viabilidad de Lactobacillus delbrueckii sometido a Jugos Gástricos Simulados. Inf Tecnol, 2015, 26 (5), 11-16.

[3] Ranadheera, R. D.; Baines, S. K; Adams, M. C. Importance of food in probiotic efficacy. Food Res Int, 2010, 43 (1), 1-7.

[4] Ray, S., Raychaudhuri, U.; Chakraborty, R. An overview of encapsulation of active compounds used in food products by drying technology. Food Biosci, 2016, 13, 76-83.

[5] Guarner, F.; Shaafsma, G. Probiotics. International Journal Microbiology. 1998, 39, 237-238.

[6] Shah, N.P. From Bulgariam milks to probiotics fermented milks. 
In IDF World Dairy Summit, Parma Italy, October 15 - 19, 2011.

[7] Fritzen-Freire, C. B.; Prudencio, E. S.; Amboni, R. D.; Pinto, S. S. Microencapsulation of bifidobacteria by spray drying in the presence of prebiotics, Food Res Int, 2012, 45 (1), 306-312.

[8] Strasser, S.; Neureiter, M.; Geppl, R.; Braun, R.; Danner, H. Influence of lyophilization, fluidized bed drying, addition of protectants, and storage on the viability of lactic acid bacteria. J App Microbiol. 2009, 107, 167-177.

[9] Shamekhi, F. M.; Shuhaimi, A.; Ariff, B; Yazid, A. M. Optimization of a cryoprotective medium for infant formula probiotic applications using response surface methodology. Ann Microbiol, 2012, 62, 911-921.

[10] Kearney, X. C., Stanton, C.; Kelly, J.; Fitsgerald. G. F.; Ross, R. P. Development of a spray dried probiotic yogurt containing Lactobacillus paracasei NFBC 338. Int. Dairy J, 2009, 19, 684-689.

[11] Champagne, C. P.; Ross, R. P.; Saarela, M.; Hanen, K. F.; Charalampopoulos, D. Recomendations for the viability asessment of probiotics as concentrated cultures in a food matrices, Int J Food Microbiol, 2011, 149, 185-193.

[12] Martin, J.M.; Lara-Villoslada, F.; Ruiz, M.A.; Morales, M.E. Microencapsulation of bacteria: A review of different technologies and their impact on the probiotic effects. Innovative Food Science and Emerging Technologies 2015, 27, 15-20.

[13] Zhao, G.; Zhang. Effect of protective agents, freezing temperature, rehydration media on viability of malolactic bacteria subjected to freeze-drying. J App Microbiol, 2005, 99, 333-338. 